\title{
"Patriotism à la Carte": Perceived Legitimacy of Collective Guilt and Collective Pride as Motivators for Political Behavior
}

\author{
Mark H. White II \\ University of Kansas \\ Nyla R. Branscombe \\ University of Kansas
}

\begin{abstract}
Intergroup emotions motivate behavior, yet little is known about how people perceive these emotional experiences in others. In three experiments $(N s=109,179,246)$, we show that U.S. citizens believe collective guilt is an illegitimate emotional motivator for ingroup political behavior, while collective pride is legitimate. This differential legitimacy is due to the perception that collective guilt violates the norm of group interest, while collective pride adheres to it; those who believe ingroup interests are more important than outgroups' exhibited this illegitimacy gap. The perception that the intergroup emotion promoted ingroup entitativity mediated the relationship between emotion (pride vs. guilt) and legitimacy; this relationship was especially strong for those high in the belief in the norm of group interest. Collective guilt can have prosocial consequences, yet the perception that it is illegitimate may hinder such consequences from being realized.
\end{abstract}

KEY WORDS: collective guilt, collective pride, entitativity, group interest, intergroup emotions

In his 2014 cover story for The Atlantic, "The Case for Reparations," Ta-Nehisi Coates asks how Americans are to make sense of their country's history, given the hundreds of years of anti-Black discrimination in the United States:

The last slaveholder has been dead for a long time. The last soldier to endure Valley Forge has been dead much longer. To proudly claim the veteran and disown the slaveholder is patriotism à la carte... If Thomas Jefferson's genius matters, then so does his taking of Sally Hemings' body. If George Washington crossing the Delaware matters, so must his ruthless pursuit of the runagate Oney Judge.

Coates argues that if Americans wish to feel proud of their country's moral and military successes, they must also grapple with the guilt associated with the United States' failures in these areas. To wrap oneself in the former and delegitimize the latter, Coates argues, is to be selective in national memory. Discursive analyses reveal that politicians and citizens alike legitimize collective pride and delegitimize collective guilt, and some philosophers agree (e.g., Augoustinos \& LeCouteur, 2004; Clark, 2008). Our goal here is to experimentally examine two questions: Do people perceive 
collective pride to be a more legitimate emotion than collective guilt as a basis for political actions? And if so, why? In line with research on intergroup emotions and self-categorization, we propose that U.S. citizens $d o$ find collective pride as more legitimate than collective guilt; we also propose that this is-at least in part-due to group members perceiving collective pride as protecting the interests of the group more than collective guilt. We review previous research supporting each of these propositions before presenting the studies.

\section{Intergroup Emotions}

Members of individualistic cultures - such as the United States-are used to thinking of emotions as individual experiences and preferences. But people can have feelings due to the groups that they belong to-intergroup emotions (Mackie, Smith, \& Ray, 2008). This is most likely when people categorize themselves in terms of their membership in a specific group instead of as an individual (Turner, Hogg, Oakes, Reicher, \& Wetherell, 1987). What intergroup emotion is felt depends on the group and context in which people self-categorize. In mid-November, an American might report fear and anger when they self-categorize as a Democrat if a Republican is elected president; this same individual might report excitement and happiness when self-categorizing as an Alabama football fan if their team is undefeated (see Smith, Seger, \& Mackie, 2007). Group membership generates intergroup emotions either because individuals evaluate events in accordance with how those affect the group (not them as individuals) or because group members are influenced by and thereby come to feel what they believe other group members feel (Mackie et al., 2008; Reysen \& Branscombe, 2008).

While people can feel emotions based on what is happening with their group contemporarily (e.g., Crisp, Heuston, Farr, \& Turner, 2007; Rothschild, Landau, Molina, Branscombe, \& Sullivan, 2013) or in the future (Caouette, Wohl, \& Peetz, 2012; Ferguson \& Branscombe, 2010), we focus on emotions due to what their group has done in the past. A large body of research demonstrates that people feel emotions based on their group's history (Branscombe \& Doosje, 2004); for example, people can feel nostalgia for their nation's history, even though they did not personally experience those times (e.g., Baldwin, White, \& Sullivan, 2018; Smeekes, Verkuyten, \& Martinovic, 2015). Two of the most investigated past-oriented intergroup emotions are guilt and pride.

Collective Guilt. People feel collective guilt when they self-categorize with a group that they consider responsible for wrongful behavior (Ferguson \& Branscombe, 2014). The wrongful behavior often occurred before the participant was even born; for example, Dutch participants reported collective guilt when reminded of the colonial history of the Dutch in Indonesia (Doosje, Branscombe, Spears, \& Manstead, 1998). Collective guilt has a number of beneficial consequences for intergroup reconciliation. White American guilt predicts less anti-Black racism (Powell, Branscombe, \& Schmitt, 2005); European Canadian guilt predicts greater willingness to apologize for policies that harmed Chinese immigrants (Wohl, Matheson, Branscombe, \& Anisman, 2013); White South African guilt about apartheid predicts greater support for affirmative action policies; and collective guilt promotes support for reparations in a variety of contexts (e.g., Brown, González, Zagefka, Manzi, \& Čehajić, 2008; Imhoff, Bilewicz, \& Erb, 2012; Schmitt, Miller, Branscombe, \& Brehm, 2008). Another closely related, self-focused, and aversive emotion - that of collective shame-has been shown to have similar effects to collective guilt, including support for reparations (Brown et al., 2008; Gausel \& Leach, 2011). Consequently, we expect that observers will not differentiate between these two emotions.

Nevertheless, people are adept at avoiding the aversive experience of collective guilt (and shame) and the threat to positive social identity it entails. People can reduce their identification with the perpetrator group, minimize their group's responsibility for the harm done, and legitimize the group's harm to prevent feeling collective guilt (Branscombe, 2004; Ferguson \& Branscombe, 2014; Wohl, Branscombe, \& Klar, 2006). It is far more likely that people willingly experience the positive emotion of collective pride. 
Collective Pride. This is, unsurprisingly, a widely felt emotion, particularly in the United States; $81 \%$ of Americans report feeling "extremely" or "very" proud to be an American-and this rate is at a 15-year low (Jones, 2016). People feel collective pride when they self-categorize with a group that has an admirable quality or is responsible for admirable behavior (Liu, Lai, Yu, \& Chen, 2014). National history is a potent resource from which to derive collective pride, as has been demonstrated in the United States, Nordic countries, Eastern Europe, Canada, and Ghana, among others (Andrews, McGlynn, \& Mycock, 2010; Evans \& Kelley, 2002; McDonnell \& Fine, 2011); history is often presented in textbooks to induce collective pride (Bromley, 2011; Foss, 2014; Nelson, 2002).

There is less research on the intergroup effects of feeling collective pride, but some research shows that it can be positively or negatively correlated with collective guilt and that it can facilitate positive or negative intergroup attitudes depending on the social context (Mashuri \& Zaduqisti, 2014; Quin, 2010; Schori-Eyal, Tagar, Saguy, \& Halperin, 2015; van Leeuwen, van Dijk, \& Kaynak, 2013). However, our focus is not on the effects of feeling either collective guilt, shame, or pride; instead, we ask how people perceive others who reportedly experience these emotions. Are these emotions perceived to be equally legitimate experiences-particularly as a basis for political behavior?

\section{The Illegitimacy of Guilt}

People frequently conceptualize emotions in individualistic terms, and guilt is no exception. Many philosophers define guilt as a negative affective state that occurs when a person feels a sense of personal culpability for a wrongful act (Clark, 2008; Darby \& Branscombe, 2014; Tollefsen, 2006) and that individuals should not bear moral responsibility for the wrongful actions of a group (Darby \& Branscombe, 2014; Tollefsen, 2006). From this perspective, feeling collective guilt is irrational, and, if it is felt, it is only "metaphoric" guilt (Arendt, 2003, p. 28). For example, French (1998) argues that if all Americans are guilty of the My Lai massacre, then we must demonstrate how each and every American "contributed materially" to it (p. 5). People who bear no individual responsibility for the My Lai massacre are not guilty, so it is irrational for them to feel guilty. Arendt (2003) takes this further in saying that it is morally wrong — or at least a "moral confusion" - to feel guilt on behalf of the actions of others, as it cheapens the blame on those who are personally culpable of the wrongful behaviors (p. 28). Political pundits' moral panic about "preaching White guilt" in reaction to schools educating students about racial privilege or wrongful acts in American history provides a concrete example of collective guilt being seen as illegitimate (e.g., Salazar, 2016; Tancredo, 2016).

Yet, for the same reasons, people are not personally responsible for the admirable behaviors of groups they belong to either. Does this render collective pride illegitimate? Apparently the same logic does not apply: Tollefsen (2006) notes that feeling pride on behalf of the group is uncontroversial, while guilt is. Clark (2008) quotes a human rights activist in Serbia: "If we collectively take pride in the successes of our basketball players, for which we have no individual credit, are we entitled to reject the feeling of guilt for our 'ethnic' crimes in which we have not individually participated?" Clark says that this question is "based upon a flawed analogy... it is neither useful nor constructive to compare pride with guilt, since only the former can be vicarious" (pp. 670-671, emphasis ours). No reason is provided for why only pride can be vicarious.

Tollefsen (2006) claims that the notion that guilt requires personal culpability is commonsense among lay people. The only empirical evidence for this, to the best of our knowledge, is based on interviews and discursive readings of political speeches. Augoustinos and LeCouteur (2004) examined Australian citizens' arguments against apologizing for the human rights violations of the Australian government toward Indigenous Australians. Many argued that present generations should not have to accept the responsibility of past generations, obviating the possibility of feeling guilt. Others argued that history is in the past and people should focus on how things are in the present (see also Wetherell and Potter [1992] for analogous evidence in New Zealand and Klandermans, Werner, \& van Doorn, 
[2008] for evidence from South Africa). Augoustinos and LeCouteur (2004) also analyzed a speech from John Howard, then Australian prime minister, which employed many of the same rhetorical arguments repudiating the legitimacy of Australians feeling collective guilt. Howard explicitly mentioned both pride and guilt, saying that the "overwhelming majority of Australians [are] proud of what this country has achieved," and that, "Australians of this generation should not be required to accept the guilt and blame for past actions and policies over which they had no control" (p. 254). Implicit here is that it is legitimate to feel pride for the ingroup's historical actions that one had nothing to do with, but it is illegitimate to feel guilt for them. The first goal of the present research is to demonstrate experimentally that people believe feeling collective pride for ingroup historical events and achievements is more legitimate than feeling collective guilt. Our second goal is to investigate why people have these perceptions.

\section{Group Interest and Entitativity}

We argue that group members find collective pride more legitimate than collective guilt because the latter violates the norm of group interest, while the former adheres to it. Social psychology has long demonstrated that people favor their ingroup over outgroups (e.g., Sherif \& Sherif, 1969; Tajfel \& Turner, 1986). This is not only a descriptive norm, but also a prescriptive one: Members feel obligated to act in their group's best interest (Montoya \& Pittinsky, 2012; Tajfel, 1970; Wildschut, Insko, \& Gaertner, 2002). Wildschut et al. (2002) name this phenomenon the "norm of group interest," "which dictates that one should take into account the interest of one's own group before taking into account the interest of other groups" (p. 976). In a prisoner's dilemma game, participants were more competitive with outgroup members ("Group B") when ingroup members ("Group A") were present or provided social support (Wildschut et al., 2002). Students allocated less money to a rival school when primed to think competitively towards them, and this was especially the case for those who endorsed the norm of group interest (Montoya \& Pittinsky, 2012).

We predict that people who endorse the norm of group interest will perceive collective pride as more legitimate than collective guilt, but those who do not endorse this norm will perceive the emotions as equally legitimate. We argue that this is because people see collective pride as promoting ingroup entitativity, which fosters group interest; conversely, collective guilt harms ingroup entitativity, undermining group interest.

Entitativity refers to a group's perceived unity, cohesion, and consistency (Campbell, 1958; Hamilton \& Sherman, 1996; Lickel et al., 2000). High entitativity provides group members with a number of benefits: promoting group esteem (Bougie, Usborne, de la Sablonnière, \& Taylor, 2011; Reysen, Katzarska-Miller, Nesbit, \& Pierce, 2013; Sani, Bowe, \& Herrera, 2008), increasing identification with the ingroup (Castano, Yzerbyt, \& Bourguignon, 2003), managing existential terror (Castano, Yzerbyt, Paladino, \& Sacchi, 2002), among others (e.g., Crawford \& Salaman, 2012).

For the present research, the most notable benefit is that people perceive entitative groups as especially capable of carrying out the group's interests. Yzerbyt, Castano, Leyens, and Paladino (2000) proposed that "group members experience an entitative ingroup as being in a better position to act upon its agenda than a less entitative group" (p. 286). Indeed, high entitative groups are perceived as more capable of achieving their interests than low entitative groups (Callahan \& Ledgerwood, 2016; Clark \& Thiem, 2015; Clark \& Wegener, 2009; Rydell \& McConnell, 2005); additionally, strong arguments are assumed to have come from more entitative groups than weak arguments (Clark \& Wegener, 2009). Arguments from high entitative groups elicit more effortful thought; so strong arguments from these groups are more persuasive than similar arguments from low entitative groups (Clark \& Thiem, 2015; Clark \& Wegener, 2009; Rydell \& McConnell, 2005).

People are apprehensive about whether entitative groups might harm the ingroup. Newheiser and Dovidio (2015) showed that people are more likely to aggress against members of a highly 
entitative rival political party, but only if those members could not retaliate, presumably because the highly entitative group members would be more capable of retaliating successfully. High entitative outgroups-compared to low entitative ones-are worrisome, because they are seen as especially capable of harming the ingroup (e.g., Abelson, Dasgupta, Park, \& Banaji, 1998; Yzerbyt et al., 2000).

Ingroup entitativity leads members to believe that the group's interests are more likely to be met. We hypothesize that people who strongly subscribe to the norm of group interest-compared to those who do not-see collective pride as promoting ingroup cohesion better than collective guilt because these people are particularly attuned to looking for ingroup members who are helping (or harming) the ingroup. This sense of perceived entitativity supportiveness should, in turn, lead people to see collective pride as more legitimate than guilt.

\section{The Current Studies}

We tested these hypotheses in three studies with American participants, using the United States as the relevant ingroup. We tested whether collective pride was seen as a more legitimate collective emotion than collective guilt in Study 1, while also considering other positive and negative collective emotions (i.e., anger, sadness, happiness). In Study 2, we investigate whether this effect depends on how much group members subscribe to the norm of group interest, predicting that those high in the belief that the ingroup's interests are paramount—compared to those low in this belief-would perceive collective guilt as less legitimate than pride. We then examine the role of entitativity in Study 3, testing the hypothesis that those high in the norm of group interest would be especially likely to see collective pride as promoting ingroup entitativity more so than collective guilt, which in turn would result in the perception that collective pride is the more legitimate emotion.

\section{STUDY 1}

We hypothesized that collective pride is perceived as a more legitimate motivation for political behavior than collective guilt. We chose political behavior as the consequence of these emotions because they are frequently tied to political agendas (e.g., Augoustinos \& LeCouteur, 2004). Since pride is a positive emotion and guilt a negative one, we also tested the perceived legitimacy of happiness, anger, and sadness at the collective level to experimentally address the effects of valence.

\section{Methods}

We recruited 116 introductory psychology students to participate in groups of one to five people. We excluded four people who showed evidence of random responding or not taking the survey seriously, two people due to missing data, and one person who met both exclusion categories. We conducted all analyses on the remaining 109 participants. Participants were $45 \%$ female, $81 \%$ White, and averaged 19.34 years old ( $S D=1.72$, range 18 to 32 ).

Participants read about five individuals who were motivated to take political action, each motivated by a different collective emotion. Since participants might have inferred different political behaviors from the different types of emotions, we told participants specifically what types of political behavior these individuals were engaging in: campaigning for the candidates and policies that they prefer and registering to vote for the first time. Participants were told that each person was motivated to participate due to a different emotion about "what has happened throughout American history." Participants read about all five people, each of whom was motivated by pride, happiness, anger, sadness, or guilt. Participants read about these people in a randomized order, creating five within-subject conditions.

Perceived legitimacy of emotions. For each target who was described as feeling a specific collective emotion, we asked participants to indicate how much they agreed with four questions on a 7-point scale: "[Emotion] is a legitimate motivator for being more involved in politics"; "[Emotion] 
is a genuine motivator for political beliefs"; "[Emotion] is a foolish reason to have certain political attitudes"; and "One shouldn't be motivated to participate simply because they feel [emotion]." The last two of these items were reverse-scored, and all four items were averaged together to measure the perceived legitimacy of each collective emotion $(.80<\alpha \mathrm{s}<.86)$.

Perceived political identification of target. We also asked participants how much they believed each target was liberal (1) to conservative (7) and Democrat (1) to Republican (7). These scores were averaged together to measure perceived political identity, with high scores indicating more perceived right-wing identification of the target $(.67<r s<.81)$.

Political and national identity. We asked participants their own political identification using the same two political identification questions $(r=.79, p<.001)$. Lastly, we measured national identity with four items: "I often think of myself as an American"; "Being American is important to me"; "I am glad that I am an American"; "and "I find the sight of the American flag very moving" $(\alpha=.89)$.

\section{Results}

Perceived legitimacy of emotions. We tested if participants saw significant differences in the legitimacy of feeling the five collective emotions using a one-way, within-subjects analysis of variance (ANOVA). This analysis was significant, $F(4,432)=35.98, p<.001, \eta_{\mathrm{p}}{ }^{2}=.25$. Pairwise comparisons revealed that all emotions differed from one another in perceived legitimacy, $p<.010$, except for anger and happiness, $p=.527$ (Figure 1). Pride was the most legitimate collective emotion, and guilt was the least.

Perceived political identification of target. We submitted perceived political identification scores to the same ANOVA, which was significant, $F(4,432)=14.08$,

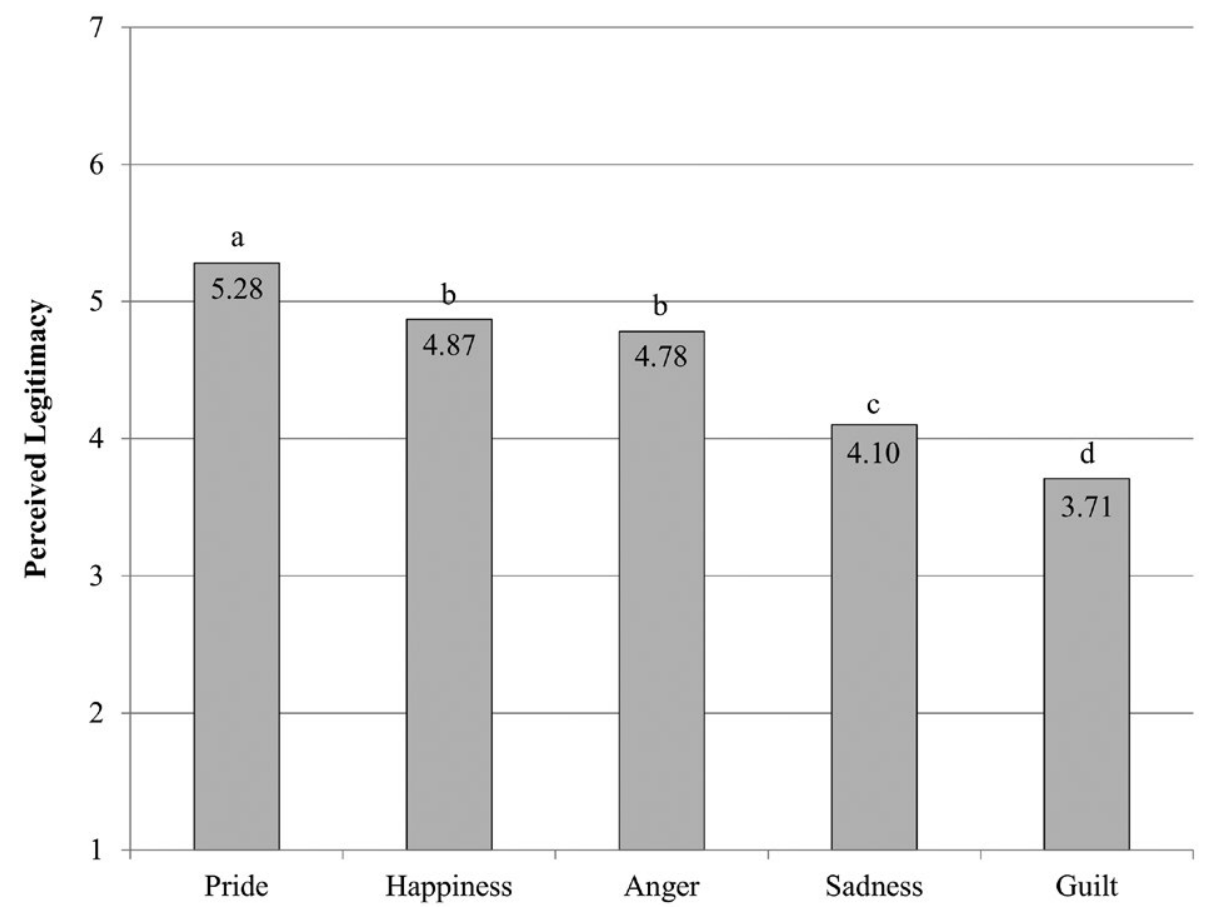

Figure 1. Pride is perceived as the most legitimate collective emotion for motivating political behavior; guilt is seen as the least legitimate (Study 1). Columns that have different superscripts have significantly different means, which are reported just below the superscripts. 
$\eta_{\mathrm{p}}{ }^{2}=.12$. Pairwise comparisons revealed that pride $(M=4.68, S D=1.34)$ and anger $(M=4.32$, $S D=1.52)$ were rated most conservative, and about equally so, $p=.083$. Guilt $(M=3.56, S D=1.17)$, sadness $(M=3.64, S D=1.00)$, and happiness $(M=3.78, S D=1.27)$ were each rated as less conservative than pride and anger, $p \mathrm{~s}<.020$. Guilt, sadness, and happiness were perceived as equally nonconservative, $p s>.21$.

Perceived legitimacy, political identification, and national identification. We also correlated perceived legitimacy of specific emotions with participants' own political and national identification. Correlations revealed that conservatism predicted greater legitimacy of pride, $r=.28, p=.003$, less legitimacy of sadness, $r=-.20, p=.041$, and guilt, $r=-.17, p=.073$. National identification predicted greater perceived legitimacy of pride, $p=.39, p<.001$ and happiness, $r=.16, p=.097$. No other correlations were significant, $p \mathrm{~s}>.11$.

\section{Discussion}

People perceived collective pride as a more legitimate emotional motivator for other political action than collective guilt. This did not appear to be a function of emotion valence, as a mixture of positive and negative collective emotions were perceived as not as legitimate as pride but more legitimate than guilt. Given targets were motivated to participate in politics, we also measured the perceived political orientation of the target: The person feeling collective pride was judged to be more conservative than the target feeling collective guilt. Participants' own conservatism and national identification predicted increased legitimacy of collective pride. These exploratory analyses provided evidence to include participant political and national identification as covariates in subsequent studies. In Studies 2 and 3, we investigated the process by which people believe collective pride is a more legitimate emotional motivator for political behavior than collective guilt.

\section{STUDY 2}

We hypothesized that collective pride is more legitimate because it adheres to the norm of group interest, whereas collective guilt flouts it. We predict that those high in adherence to the norm of group interest will display the pride-guilt legitimacy gap, while those low in the norm will not.

We also sought to examine the perception of collective shame. Negative aspects of one's ingroup can elicit collective guilt and collective shame, both aversive intergroup emotions. One of the primary differences between the two is the controllability of the antecedent: Collective guilt is felt when reminded of controllable aspects of an ingroup, while collective shame is elicited by the salience of uncontrollable aspects of an ingroup (Branscombe, Slugoski, \& Kappen, 2004). Collective guilt is about what the group has done, while collective shame is about how the group is or what has happened to the group. We tested if people perceive this theoretical difference in volition and if these emotions differ in their perceived legitimacy.

\section{Methods}

We recruited 180 people from Amazon's Mechanical Turk (MTurk) to participate in the study. We excluded one participant from all analyses because he did not identify as an American citizen. Participants were 50\% female, 79\% White, and averaged 37.38 years old ( $S D=12.36$, range 18 to 66).

Participants read about one individual who is politically active for the first time, using the same description of behaviors as Study 1. Each participant was randomly assigned to read one of three reasons why this person was participating: pride, guilt, or shame about America's past. Participants were then asked "what kind of events or topics in American history" they believed the target was 
thinking about when the target felt the collective emotion. Participants were asked to write down these events or topics.

Volition. Participants indicated on a 7-point Likert scale their agreement with the following statements about the event or topic they just wrote about: "Americans were in control of this happening"; "This happened because of what Americans did"; and "Americans wanted this to happen" $(\alpha=.76)$.

Image threat. Participants then responded to three questions gauging the threat to group image the topic or event they wrote about had: "Does this make America look good or bad?" (1 = very bad to $7=$ very good $)$, "Does this put America in a positive or negative light?" $(1=$ extremely negative to 7 = extremely positive), and "This threatens America's positive image in the world" $(1=$ strongly disagree to $7=$ strongly agree). We averaged these items together, reverse-scoring the first two items $(\alpha=.90)$ so that higher scores reflected greater threat to the ingroup's image.

Legitimacy. The same four items were used to assess legitimacy of the emotion as in Study 1 $(\alpha=.88)$.

Norm of group interest. Participants indicated on a six-item, 7-point scale how much they endorsed the norm of group interest as it applied to the United States (Montoya \& Pittinsky, 2012). An example item is: "I feel that most Americans expect that other Americans will do everything they can do to support America" ( $\alpha=.81)$.

Political and national identity. We measured participants' political identity the same as in Study $1(r=.91, p<.001)$, and we used the first three items of the national identity scale from Study $1(\alpha=.95)$.

\section{Results}

Volition. We first tested if people perceive the theoretical difference between guilt and shamethat guilt involves volition on the part of the group, whereas shame does not. We submitted perceptions of group volition in the event participants wrote about a one-way, between-subjects ANOVA. There was a significant effect of condition (pride vs. shame vs. guilt), $F(2,176)=9.46, p<.001$, $\eta_{\mathrm{p}}{ }^{2}=.10$. Pairwise comparisons revealed that events associated with collective pride $(M=5.71$, $S D=0.90)$ were perceived as more volitional than both guilt $(M=4.97, S D=1.23)$ and shame $(M=4.92, S D=1.19), p s<.001$. A planned contrast between guilt and shame revealed that participants perceived their antecedents as equally volitional, $t(176)=0.23, p=.818, d=.04[-.32, .40]{ }^{1}$ For all subsequent analyses, we collapsed the guilt and shame conditions together. ${ }^{2}$

Image threat. Participants thought that guilt and shame $(M=5.41, S D=1.17)$ threatened America's image more than pride $(M=2.29, S D=1.17), t(177)=16.95, p<.001, d=2.67[2.26,3.09]$.

Perceived legitimacy. We then tested if participants thought that guilt and shame were less legitimate motivators for political involvement than pride-a replication of our effect in Study 1. Participants thought that guilt and shame $(M=4.71, S D=1.34)$ were less legitimate collective emotions than pride $(M=5.20, S D=1.26), t(177)=-2.34, p=.020, d=-.37[-.68,-.06]$.

The role of norm of group interest. We predicted that people perceive pride as a more legitimate collective emotion than guilt and shame because feeling guilt and shame violates the norm of group interest. We tested this by seeing if the effect of collective emotion type on legitimacy would be strongest for those who highly endorsed the American norm of group interest. We accomplished this by using condition $(0=$ pride, $1=$ guilt and shame), norm of group interest, and the interaction between the two to predict the perceived legitimacy of the collective emotion (mean-centering predictors). The model was significant, $R^{2}=.13, F(3,175)=8.98, p<.001$. The more participants perceived

\footnotetext{
${ }^{1}$ All confidence intervals are at the $95 \%$ level.

${ }^{2}$ Results for primary hypotheses were the same in direction and significance when not collapsing guilt and shame together.
} 
a norm of group interest in America, the more legitimate they thought the emotion was (regardless of emotion), $b=.30, S E=.11, t(175)=2.85, p=.005$; participants in the guilt and shame condition perceived the emotion as less legitimate, $b=-.43, S E=.20, t(175)=-2.15, p=.033$.

These main effects were qualified by a significant interaction, $\Delta R^{2}=.05, b=-.70, S E=.21$, $t(175)=-3.26, p=.001$ (Figure 2). We probed this interaction by examining the effect of condition for those at $-1 S D$ (low) and $+1 S D$ (high) on perceived norm of group interest (Model 1; Hayes, 2013). For those who perceived low norm of group interest in America, there was no effect of condition, $b=.20, S E=.28, t(176)=0.72, p=.475$. For those high in perceived norm of group interest, pride was seen as more legitimate than guilt and shame, $b=-1.05, S E=.27, t(175)=-3.88, p<.001$.

Ancillary analyses. In Study 1, we found that people who are motivated because of guilt are seen as less conservative than those motivated by pride; moreover, conservatism and national identity predicted less perceived legitimacy of guilt. Because the norm of group interest correlates with conservatism $(r=.24, p=.001)$ and national identity $(r=.53, p<.001)$, we tested the same condition by the norm of group-interest interaction after controlling for conservatism and national identity. The interaction remained significant, $\Delta R^{2}=.06, b=-.73, S E=.21, t(175)=-3.45, p<.001$.

We also examined if threat to ingroup image might explain the relationship between type of emotion and legitimacy; we did this by testing the indirect effect of emotion type on legitimacy through image threat using the PROCESS macro for SPSS (Model 4; Hayes, 2013) with 10,000 bias-corrected bootstrap resamples. This indirect effect was not significant, -.09 [-.81, .62].

\section{Discussion}

Collective pride was seen as a more legitimate motivator of others' political action than collective guilt and shame. Using a between-subjects design and sampling from a different population, we replicated the effect found in Study 1. This provides evidence that our effect in Study 1 was

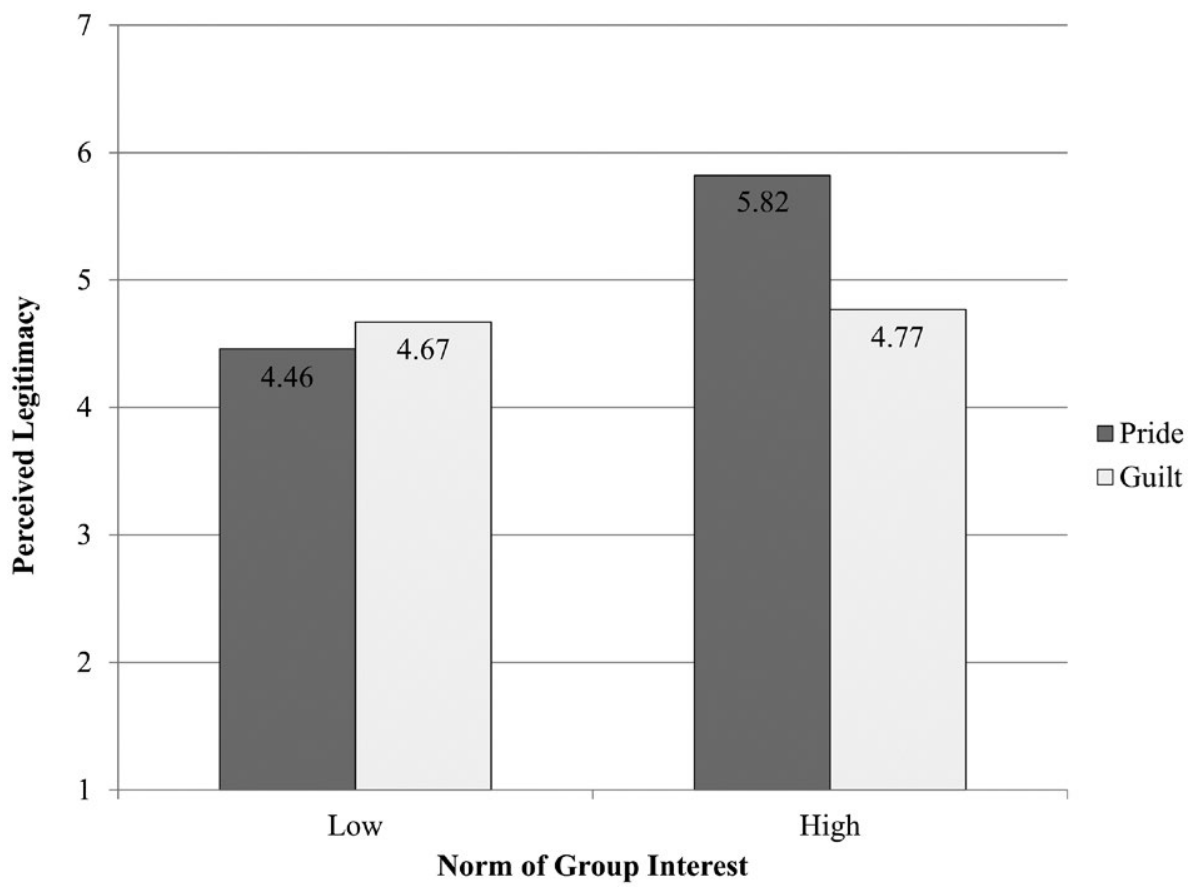

Figure 2. Pride is seen as a more legitimate collective emotion, but only for those high in norm of group interest (Study 2). 
not simply due to participants contrasting collective guilt and collective pride in a within-subjects design. We also found evidence supporting the hypothesis that this legitimacy gap is driven by the norm of group interest, as the effect was only found for participants who endorsed the norm that the ingroup's goals take precedence over outgroups' goals.

Although there is a theoretical distinction between collective guilt and collective shame for those who experience these emotions in terms of the controllability of the antecedent (Branscombe et al., 2004), our participants did not perceive this volitional difference, nor did it influence the perceived legitimacy of others' acting on these emotions. This raises the possibility that the effects demonstrated for collective guilt in Studies 1 and 3 might also hold for collective shame, as well; research on how people perceive collective guilt and collective shame is virtually nonexistent-and a promising route for future research. We also demonstrated that the role of the norm of group interest is not due to national or political identification and that threat to the ingroup's image alone cannot explain the difference in legitimacy. In Study 3, we examine the role of entitativity supportiveness of the collective emotion in perceptions of legitimacy.

\section{STUDY 3}

We hypothesized that collective pride is seen as a more legitimate emotional motivator for political action than collective guilt because those who adhere to the norm of group interest find the former to be more supportive of ingroup entitativity than the latter. Those who adhere to the norm that the ingroup's goals are paramount should be especially likely to perceive collective pride as more entitativity supportive than collective guilt; since people perceive entitative groups as especially capable of achieving their goals (e.g., Clark \& Thiem, 2015; Clark \& Wegener, 2009), this entitativity supportiveness should in turn predict legitimacy of the intergroup emotion.

\section{Methods}

We recruited 250 people from MTurk to participate in the study. We excluded two participants for partial responding and two participants who did not identify as an American citizen. All analyses were performed on the resulting sample of 246 participants. Participants were $46 \%$ female, $70 \%$ White, and averaged 33.60 years old $(S D=11.00$, range 18 to 74). Participants from Study 2 were excluded from taking part in Study 3 (Litman, Robinson, \& Abberbock, 2016).

Participants first filled out the same norm of group interest scale $(\alpha=.79)$, political identity $(r=.90, p<.001)$, and national identity $(\alpha=.95)$ questions as in Study 2 . The procedure was the same as in Study 2, but participants were randomly assigned to either a pride or a guilt condition. Participants read about someone motivated to participate in politics for the first time because of either pride or guilt, wrote down what from American history they thought made the target feel that way, and then answered a brief questionnaire.

Image threat. We used the same three items as in Study 2 to assess ingroup image threat $(\alpha=.91)$.

Support for entitativity. We adapted items from various entitativity scales (e.g., Denson, Lickel, Curtis, Stenstrom, \& Ames, 2006; Spencer-Rodgers, Williams, Hamilton, Peng, \& Wang, 2007) to assess how much people perceived each emotion as promoting ingroup entitativity. Participants were asked 12 questions on a 1 (Definitely not) to 5 (Definitely yes) scale, each beginning with the stem, "Do feelings of [emotion] as an American..." Example items read: "...promote cohesion among Americans?" “...help Americans feel more similar to each other?" and "...promote common goals among Americans?" $(\alpha=.95)$.

Legitimacy. The same four items were used as in Studies 1 and $2(\alpha=.87)$. 


\section{Results}

Participants saw collective guilt as more threatening to the group image, promoting less ingroup entitativity, and less legitimate than collective pride (Table 1), replicating and advancing our findings from Studies 1 and 2. We hypothesized that participants whose belief in the norm of group interest is high would believe guilt promotes less entitativity and is more illegitimate than pride compared to those low in this belief. We tested these hypotheses by predicting each of the dependent variables from condition $(0=$ pride, $1=$ guilt $)$, norm of group interest, and the interaction between the two (mean-centering predictors). The interaction on both entitativity and illegitimacy were significant (Table 2). We probed both of these interactions by examining the conditional effects for those at -1 $S D$ (low) and $+1 S D$ (high) on perceived norm of group interest (Model 1; Hayes, 2013).

Entitativity. Participants low in perceived norm of group interest thought that guilt was less entitativity supportive than pride, $b=-.50, S E=.14, t(242)=-3.70, p<.001$; this effect was larger for those high in this belief, $b=-.92, S E=.14, t(242)=6.76, p<.001$ (Figure 3).

Legitimacy. Participants low in perceived norm of group interest saw guilt and pride as equally legitimate, $b=-.30, S E=.25, t(242)=-1.17, p=.244$; those high in this belief saw guilt as a less legitimate collective emotion than pride, $b=-1.01, S E=.25, t(242)=-3.96, p<.001$ (Figure 4).

Moderated mediation. We examined if the perceived entitativity-supportive nature of the collective emotion mediated the relationship between collective emotion $(0=$ pride, $1=$ guilt $)$ and perceived legitimacy of that emotion, especially for those high in belief in the norm of group interest. We accomplished this by running two separate linear regression models: First, we predicted entitativity from condition, norm of group interest, and the interaction between the two; second, we predicted legitimacy of the emotion from entitativity, norm of group interest, condition, and the norm of group interest by condition interaction. Coefficients, indirect effects, and the index of moderated mediation (Hayes, 2015) were calculated using the PROCESS macro for SPSS (Model 8; Hayes, 2013) with 10,000 bias-corrected bootstrap resamples.

As reported above, the norm of group interest by condition interaction on entitativity was significant, $p=.030$. Predicting legitimacy from entitativity, norm of group interest, condition, and the interaction between norm of group interest and condition yielded only one significant predictor: perceived entitativity supportiveness of the collective emotion, $b=.82, S E=.11, t(241)=7.55, p<$ .001 . The index of moderated mediation $=-.20[-.43,-.02]$, which indicated that participants' belief in the norm of group interest significantly moderated the indirect effect of emotion condition on legitimacy through entitativity (Figure 5).

We probed this index of moderated mediation by examining the conditional indirect effects at $-1 S D$ (low) and +1 SD (high) of norm of group interest. This revealed that the indirect effect was smaller for those low in norm of group interest (indirect effect $=-.41[-.69,-.20]$ ) than for those high in this belief (indirect effect $=-.75[-1.12,-.47]$ ).

Ancillary analyses. We again considered the role of political and national identity by controlling for each in the moderated mediation model. The index of moderated mediation remained significant even after controlling for political and national identity in both of the regression equations, -.19 $[-.42,-.01]$. We also tested the indirect effect of condition on legitimacy through ingroup threat

Table 1. Effect of Condition on Image Threat, Entitativity, and Legitimacy in Study 3

\begin{tabular}{llllll} 
& Guilt & Pride & $\boldsymbol{t}$ & $\boldsymbol{d}$ & 95\% CI \\
\hline Image Threat & $5.38(1.16)$ & $2.54(1.36)$ & 17.65 & 2.25 & {$[1.93,2.57]$} \\
Entitativity & $3.08(3.08)$ & $3.84(3.84)$ & 7.48 & 0.95 & {$[0.69,1.22]$} \\
Legitimacy & $4.01(1.52)$ & $4.73(1.36)$ & 3.90 & 0.50 & {$[0.24,0.75]$} \\
\hline
\end{tabular}

Note. "Guilt" and "Pride" columns contain means, with standard deviations in parentheses. All $t$-tests significant, $p<.001$. 
Table 2. Multiple Linear Regression Coefficients for Main Effects and Interactions in Study 3

\begin{tabular}{|c|c|c|c|c|c|}
\hline Dependent Variable & Predictor & $b$ & $S E$ & $t$ & $p$ \\
\hline \multirow[t]{3}{*}{ Entitativity } & $\begin{array}{l}\text { Norm of Group } \\
\text { Interest }\end{array}$ & .31 & .06 & 5.59 & $<.001$ \\
\hline & Emotion Condition & -.71 & .10 & -7.42 & $<.001$ \\
\hline & Interaction & -.24 & .11 & -2.18 & .030 \\
\hline \multirow[t]{3}{*}{ Legitimacy } & $\begin{array}{l}\text { Norm of Group } \\
\text { Interest }\end{array}$ & .39 & .11 & 3.68 & $<.001$ \\
\hline & Emotion Condition & -.65 & .18 & -3.64 & $<.001$ \\
\hline & Interaction & -.42 & .21 & -1.98 & .049 \\
\hline
\end{tabular}

Note. For both interactions, $\Delta R^{2}=.01$.

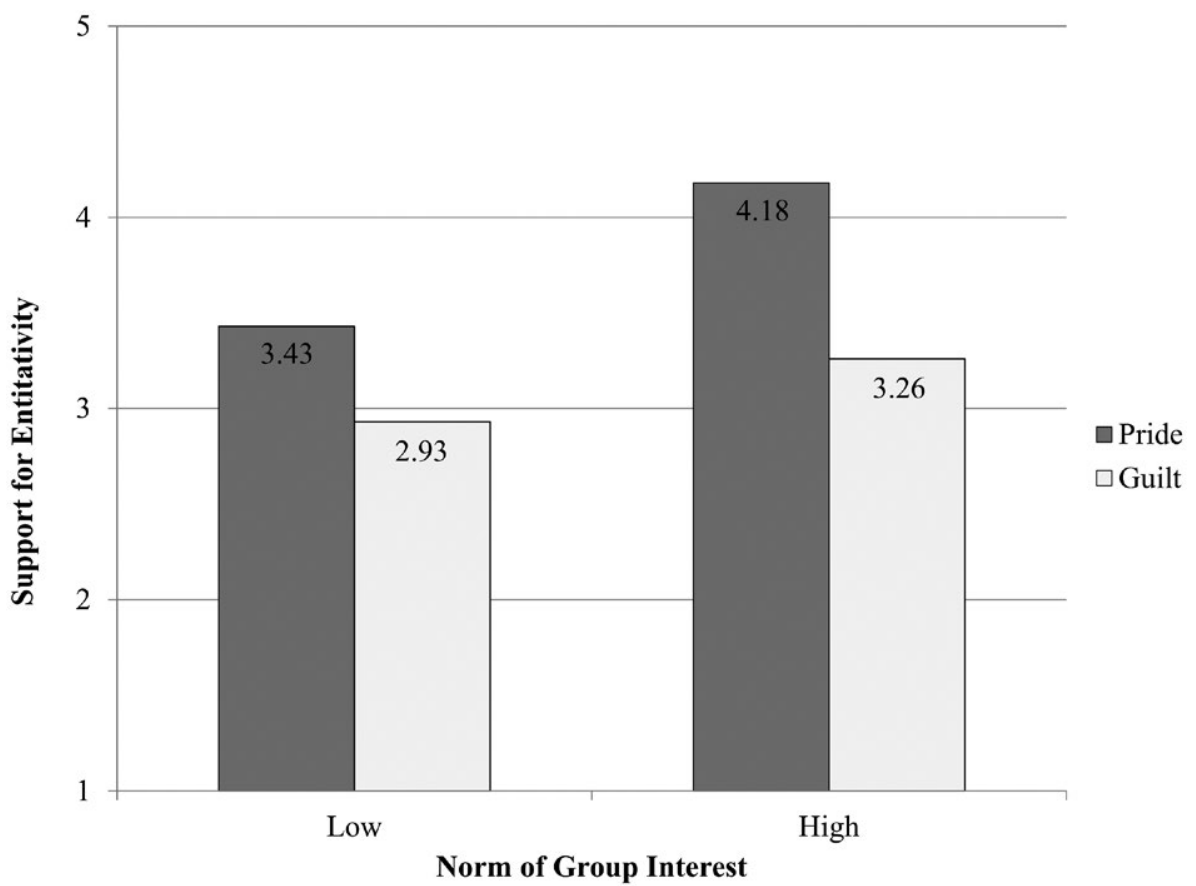

Figure 3. Pride is seen as supporting ingroup entitativity more than guilt, and this effect is especially strong for those high in norm of group interest (Study 3).

using the PROCESS macro for SPSS (Model 4; Hayes, 2013), with 10,000 bias-corrected bootstrap resamples. This indirect effect was again not significant, $-.34[-.81, .19]$.

\section{Discussion}

Consistent with Studies 1 and 2, collective pride was perceived as a more legitimate emotional motivator for political behavior than collective guilt. This effect was mediated by the perception that collective pride is more entitativity supportive than collective guilt. This indirect effect was particularly strong for those who highly endorse the norm of group interest, as they saw collective pride as 


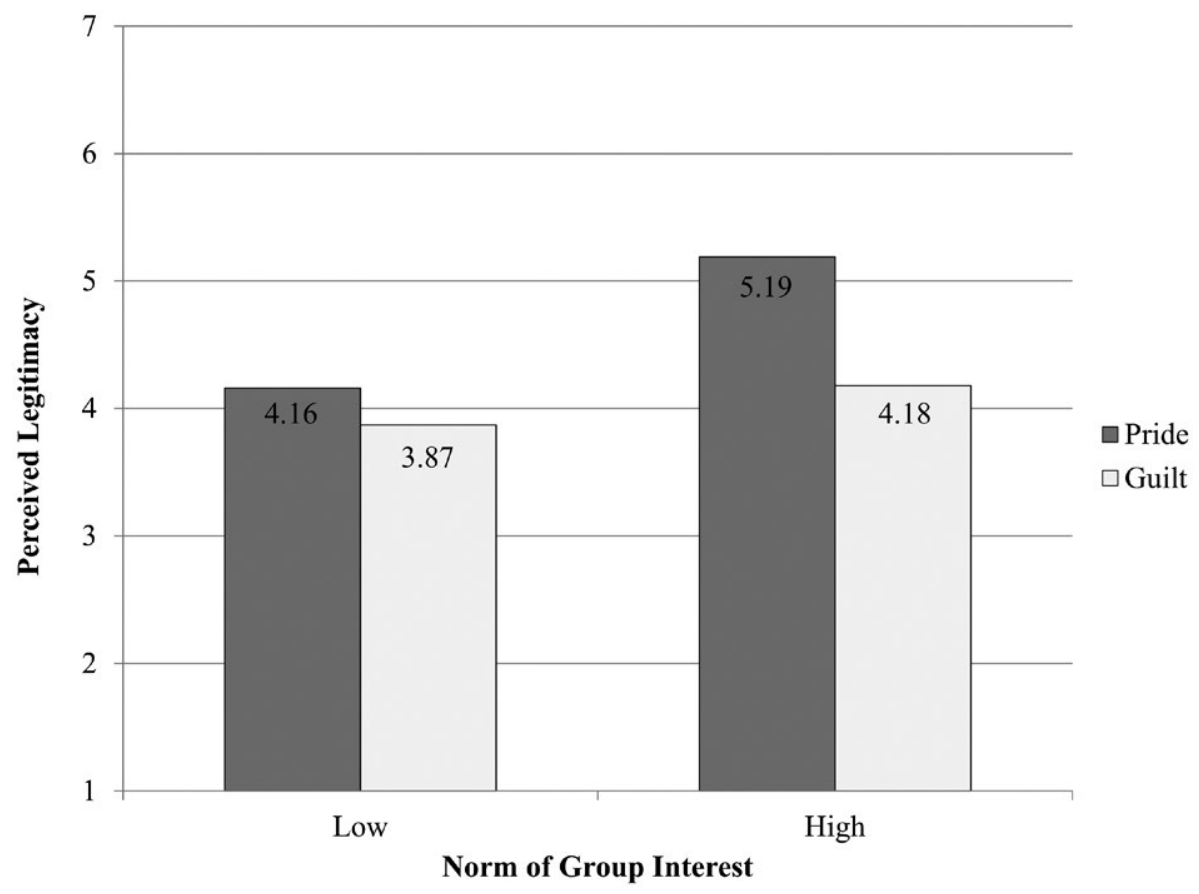

Figure 4. Pride is seen as a more legitimate collective emotion than guilt, but only for those high in norm of group interest (Study 3).

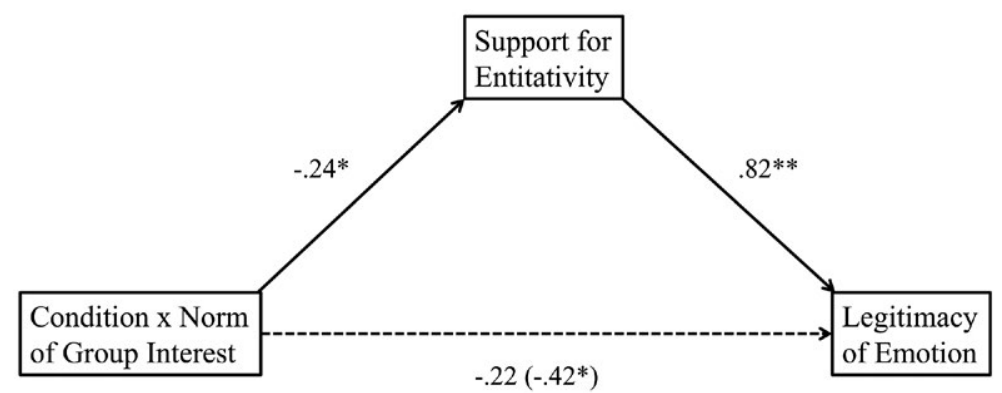

Figure 5. The moderated mediation model tested in Study 3. The coefficient in parentheses is the total effect. All coefficients are unstandardized. The main effects of emotion condition and norm of group interest predicting support for entitativity and legitimacy of emotion were included in the equations but are not depicted here. * $p<.05$, ** $p<.001$.

especially likely to support ingroup entitativity. We again ruled out the potential role of national and political identification in accounting for these effects, as well as ingroup image threat.

\section{General Discussion}

People differentially perceive the legitimacy of fellow ingroup members' emotional motivations for political behavior, with a bias in favor of collective pride over collective guilt. We found this effect in both within- and between-subjects designs as well as in a laboratory student sample and online adult samples. The difference in valence of the two emotions does not appear to explain the 
legitimacy difference, as collective pride was seen as more legitimate than happiness, while collective guilt was less legitimate than anger and sadness (Study 1).

High endorsers of the norm of group interest - that the ingroup's goals are privileged above outgroups' goals-found collective pride as more legitimate than collective guilt, but this was not true for low endorsers (Study 2). We interpret this as evidence that collective pride is seen as more legitimate because it adheres to the prevailing norm of group interest (Wildschut et al., 2002). This interaction held even after controlling for political and national identification, which were related to both perceptions of legitimacy and norm of group interest, and threat to the ingroup's image did not mediate the relationship between intergroup emotion type and perceived legitimacy as a political motivator. Future research should examine the roles of political partisanship and national identification proper as well, as we treat them as control variables in the present analysis.

Entitative groups - groups that are cohesive, unified, with similar members - are seen as more efficacious than nonentitative groups; people perceive them to be more capable of acting on their group's interests. We found that people perceive collective pride as more supportive of ingroup entitativity than collective guilt or shame, and this was especially so for those high in the norm of group interest, as these people are particularly sensitive to cues that undermine group interests. Entitativity supportiveness of the emotion, in turn, predicted legitimacy of the emotion as a political motivator (Study 3). This model held after controlling for political and national identification, and the perceived threat of the emotion poses to the ingroup's image did not mediate the relationship between emotion type and perceived legitimacy.

\section{Perceptions of Intergroup Emotions}

The antecedents and consequences of experiencing intergroup emotions, particularly collective guilt, have been extensively researched (Ferguson \& Branscombe, 2014; Mackie et al., 2008). Less is known, however, about how people perceive others' intergroup emotions; the present research begins to examine these phenomena. How people perceive others' intergroup emotions might have important implications for how people think about the consequences of those emotions. That people-especially those who adhere strongly to the norm of group interest-perceive collective guilt as undermining entitativity and less legitimate than collective pride could have important implications for how people think about the consequences of these emotions.

Emotions are motivational states (Brehm, 1999), and collective guilt motivates reparative action for the ingroup's past harm doing (e.g., Brown et al., 2008; Doosje et al., 1998; Imhoff et al., 2012). Indeed, our data do not suggest that collective guilt actually harms the ingroup; rather, we have documented a perceptual bias against others' experiencing collective guilt. There are a number of cognitive tools people can use to keep themselves from feeling collective guilt (Branscombe, 2004; Wohl et al., 2006), but our question concerns how people deal with others feeling this emotion. Our data suggest that they are likely to frame the emotional experience as illegitimate. Future research might examine how undermining the legitimacy of feeling an intergroup emotion influences messages that reflect that emotion; does undermining the emotional experience that drives one's efforts make them less persuasive? For example, one might simply write off a White American's support and arguments for affirmative action policies as symptoms of a pathological "White guilt" that can easily be ignored once rendered "irrational."

One might also examine the opposite: To what extent does bolstering the legitimacy of collective guilt increase the efficacy of political efforts that explicitly appeal to a sense of collective guilt? For example, the legitimacy of collective guilt might be bolstered by suggesting it will improve the ingroup's identity in the eyes of third parties (i.e., that the ingroup is a moral group that accepts responsibility for correcting its past wrongs). To the extent that collective guilt can be portrayed as protecting the ingroup's social identity, it may be seen as more legitimate and entitativity supporting. 
Since collective guilt is perceived to be less legitimate than collective pride, it is no surprise that efforts appealing to collective pride can be effective at improving outgroup attitudes compared to those appealing to collective guilt (van Leeuwen et al., 2013). Especially if psychologists wish to improve intergroup attitudes outside of the laboratory, it is important to study how individuals will perceive the emotional experiences such messages are designed to elicit. Since failing to do so might create efforts that backfire (e.g., Salazar, 2016), researchers may want to investigate further the consequences of intergroup emotion perceptions.

\section{Belonging to an Entitative Group}

A number of studies have demonstrated the psychological benefits of belonging to an entitative ingroup (e.g., Bougie et al., 2011; Castano et al., 2003, 2002), but the idea that an entitative group is a particularly capable one has usually been examined within the context of perceiving outgroups (e.g., Abelson, et al., 1998; Yzerbyt et al., 2000). Our results suggest that people are motivated to foster ingroup entitativity because it increases the group's competence, as people highly invested in the norm of group interest are especially sensitive to threats against entitativity.

Ingroup members who deviate from group norms are disliked more than outgroup members who do the same, and this is especially so when the ingroup's public image is jeopardized (Branscombe, Wann, Noel, \& Coleman, 1993; Marques \& Paez, 1994). If feeling collective guilt violates the norm of group interest and threatens the entitativity of one's group, ingroup members feeling collective guilt should be judged more harshly than outgroup members who feel similarly about their groups. Indeed, collective guilt may be seen as more legitimate for outgroup members to feel, as it would promote lower levels of outgroup entitativity, which can be threatening to the ingroup (e.g., Newheiser \& Dovidio, 2015). For example, White Americans who feel guilty about slavery may be punished, while Chinese citizens who undermine their nation's entitativity by feeling guilty about the Tiananmen Square protests are applauded.

\section{Conclusion}

We find evidence that Americans engage in "patriotism à la carte" (Coates, 2014) by finding collective pride a more legitimate emotion than collective guilt, and our data suggest this legitimacy difference serves to protect the group's cohesion and agenda. Researchers, then, must not only investigate the antecedents and consequences of intergroup emotional experiences, but also how ingroup members perceive people who are driven by those emotions.

\section{ACKNOWLEDGMENTS}

The second author was supported by the Canadian Institute for Advanced Research: Social Interactions, Identity and Well-Being Program. Correspondence concerning this article should be addressed to Mark H. White II, Department of Psychology, University of Kansas, 549 Fraser Hall, Lawrence, KS 66044. E-mail: markhwhiteii@ku.edu

\section{REFERENCES}

Abelson, R. P., Dasgupta, N., Park, J., \& Banaji, M. R. (1998). Perceptions of the collective other. Personality and Social Psychology Review, 2(4), 243-250. https://doi.org/10.1207/s15327957pspr0204_2

Andrews, R., McGlynn, C., \& Mycock, A. (2010). National pride and students' attitudes towards history: An exploratory study. Educational Studies, 36(3), 299-309. https://doi.org/10.1080/03055690903424782

Arendt, H. (2003). Responsibility and judgment. New York, NY: Schocken Books. 
Augoustinos, M., \& LeCouteur, A. (2004). On whether to apologize to Indigenous Australians: The denial of white guilt. In N. R. Branscombe \& B. Doosje (Eds.), Collective guilt: International perspectives (pp. 236-261). Cambridge, United Kingdom: Cambridge University Press.

Baldwin, M., White, M. H., II, \& Sullivan, D. (2018). Nostalgia for America's past can buffer collective guilt. European Journal of Social Psychology, 48(4), 433-446. https://doi.org/10.1002/ejsp.2348

Bougie, E., Usborne, E., da la Sablonnière, R., \& Taylor, D. M. (2011). The cultural narratives of Francophone and Anglophone Quebecers: Using a historical perspective to explore the relationships among collective relative deprivation, in-group entitativity, and collective esteem. British Journal of Social Psychology, 50(4), 726-746. https://doi. org/10.1348/014466610X526018

Branscombe, N. R. (2004). A social psychological perspective on collective guilt. In N. R. Branscombe \& B. Doosje (Eds.), Collective guilt: International perspectives (pp. 320-334). Cambridge, United Kingdom: Cambridge University Press.

Branscombe, N. R., \& Doosje, B. (Eds.) (2004). Collective guilt: International perspectives. Cambridge, United Kingdom: Cambridge University Press.

Branscombe, N. R., Slugoski, B., \& Kappen, D. M. (2004). The measurement of collective guilt: What it is and what it is not. In N. R. Branscombe \& B. Doosje (Eds.), Collective guilt: International perspectives (pp. 16-34). Cambridge, United Kingdom: Cambridge University Press.

Branscombe, N. R., Wann, D. L., Noel, J. G., \& Coleman, J. (1993). Ingroup or outgroup extremity: Importance of the threatened identity. Personality and Social Psychology Bulletin, 19(4), 381-388. https://doi.org/10.1177/0146167293194003

Brehm, J. W. (1999). The intensity of emotion. Personality and Social Psychology Review, 3(1), 2-22. https://doi.org/10.1207/ s15327957pspr0301_1

Bromley, P. (2011). Multiculturalism and human rights in civic education: The case of British Columbia. Canada. Educational Research, 53(2), 151-164. https://doi.org/10.1080/00131881.2011.572363

Brown, R., González, R., Zagefka, H., Manzi, J., \& Čehajić, S. (2008). Nuestra culpa: Collective guilt and shame as predictors of reparation for historical wrongdoing. Journal of Personality and Social Psychology, 94(1), 75-90. https://doi. org/10.1037/0022-3514.94.1.75

Callahan, S. P., \& Ledgerwood, A. (2016). On the psychological function of flags and logos: Group identity symbols increase perceived entitativity. Journal of Personality and Social Psychology, 110(4), 528-550. https://doi.org/10.1037/ pspi0000047

Campbell, D. T. (1958). Common fate, similarity, and other indices of the status of aggregates of persons as social entities. Systems Research and Behavioral Science, 3(1), 14-25. https://doi.org/10.1002/bs.3830030103

Caouette, J., Wohl, M. J. A., \& Peetz, J. (2012). The future weighs heavier than the past: Collective guilt, perceived control and the influence of time. European Journal of Social Psychology, 42(3), 363-371. https://doi.org/10.1002/ejsp.1857

Castano, E., Yzerbyt, V., \& Bourguignon, D. (2003). We are one and I like it: The impact of ingroup entitativity on ingroup identification. European Journal of Social Psychology, 33(6), 735-754. https://doi.org/10.1002/ejsp.175

Castano, E., Yzerbyt, V., Paladino, M., \& Sacchi, S. (2002). I belong therefore I exist: Ingroup identification, ingroup entitativity, and ingroup bias. Personality and Social Psychology Bulletin, 28(2), 135-143. https://doi. org/10.1177/0146167202282001

Clark, J. N. (2008). Collective guilt, collective responsibility and the Serbs. East European Politics and Societies, 22(3), 668-692. https://doi.org/10.1177/0888325408318533

Clark, J. K., \& Thiem, K. C. (2015). Group communicators, perceived entitativity, and persuasion: A self-validation analysis. Journal of Experimental Social Psychology, 61(1), 5-11. https://doi.org/10.1016/j.jesp.2015.06.005

Clark, J. K., \& Wegener, D. T. (2009). Source entitativity and the elaboration of persuasive messages: The roles of perceived efficacy and message discrepancy. Journal of Personality and Social Psychology, 97(1), 42-57. https://doi.org/10.1037/ $\mathrm{a} 0015450$

Coates, T. (2014). The case for reparations. Retrieved from https://www.theatlantic.com/magazine/archive/2014/06/ the-case-for-reparations/361631/

Crawford, M. T., \& Salaman, L. (2012). Entitativity, identity, and the fulfillment of psychological needs. Journal of Experimental Social Psychology, 48(3), 726-730. https://doi.org/10.1016/j.jesp.2011.12.015

Crisp, R. J., Heuston, S., Farr, M. J., \& Turner, R. N. (2007). Seeing red or feeling blue: Differentiated intergroup emotions and ingroup identification in soccer fans. Group Processes \& Intergroup Relations, 10(1), 9-26. https://doi. org/10.1177/1368430207071337

Darby, D., \& Branscombe, N. R. (2014). Beyond the sins of the fathers: Responsibility for inequality. Midwest Studies in Philosophy, 38(1), 121-137. https://doi.org/10.1111/misp.12020

Denson, T. F., Lickel, B., Curtis, M., Stenstrom, D. M., \& Ames, D. R. (2006). The roles of entitativity and essentiality in judgments of collective responsibility. Group Processes \& Intergroup Relations, 9(1), 43-61. https://doi. org/10.1177/1368430206059857

Doosje, B., Branscombe, N. R., Spears, R., \& Manstead, A. S. R. (1998). Guilty by association: When one's group has a negative history. Journal of Personality and Social Psychology, 75(4), 872-886. https://doi.org/10.1037/0022-3514.75.4.872 
Evans, M. D. R., \& Kelley, J. (2002). National pride in the developed world: Survey data from 24 nations. International Journal of Public Opinion Research, 14(3), 303-338. https://doi.org/10.1093/ijpor/14.3.303

Foss, C. (2014). Kemal Atatürk: Giving a new nation a new history. Middle Eastern Studies, 50(5), 826-847. https://doi.org/ $10.1080 / 00263206.2014 .913574$

Ferguson, M. A., \& Branscombe, N. R. (2010). Collective guilt mediates the effect of beliefs about global warming on willingness to engage in mitigation behavior. Journal of Environmental Psychology, 30(2), 135-142. https://doi.org/10.1016/j. jenvp.2009.11.010

Ferguson, M. A., \& Branscombe, N. R. (2014). The social psychology of collective guilt. In C. von Scheve \& M. Salmela (Eds.), Collective emotions: Perspectives from psychology, philosophy, and sociology (pp. 251-265). Oxford, United Kingdom: Oxford University Press.

French, P. A. (1998). The responsibility of monsters and their makers. In P. A. French (Ed.), Individual and collective responsibility. Rochester, VT: Schenkman.

Gausel, N., \& Leach, C. W. (2011). Concern for self-image and social image in the management of moral failure: Rethinking shame. European Journal of Social Psychology, 41(4), 468-478. https://doi.org/10.1002/ejsp.803.

Hamilton, D. L., \& Sherman, S. J. (1996). Perceiving persons and groups. Psychological Review, 103(2), 336-355. https://doi. org/10.1037//0033-295X.103.2.336.

Hayes, A. F. (2013). Introduction to mediation, moderation, and conditional process analysis: A regression-based approach. New York, NY: Guilford Press.

Hayes, A. F. (2015). An index and test of linear moderated mediation. Multivariate Behavioral Research, 50(1), 1-22. https:// doi.org/10.1080/00273171.2014.962683

Imhoff, R., Bilewicz, M., \& Erb, H. (2012). Collective regret versus vollective guilt: Different emotional reactions to historical atrocities. European Journal of Social Psychology, 42(6), 729-742. https://doi.org/10.1002/ejsp.1886

Jones, J. M. (2016, July 1). New low of 52\% "extremely proud” to be Americans. Retrieved from https://www.gallup.com/ poll/193379/new-low-extremely-proud-americans.aspx

Klandermans, B., Werner, M., \& van Doorn, M. (2008). Redeeming apartheid's legacy: Collective guilt, political ideology, and compensation. Political Psychology, 29(3), 331-349. https://doi.org/10.1111/j.1467-9221.2008.00633.x

Lickel, B., Hamilton, D. L., Wieczorkowska, G., Lewis, A., Sherman, S. J., \& Uhles, A. N. (2000). Varities of groups and the perception of group entitativity. Personality and Social Psychology, 78(2), 223-246. https://doi. org/10.1037//0022-3514.78.2.223

Litman, L., Robinson, J., \& Atterbock, T. (2016). TurkPrime.com: A versatile crowdsourcing data acquisition platform for the behavioral sciences. Behavior Research Methods. https://doi.org/10.3758/s13428-016-0727-z

Liu, C., Lai, W., Yu, G., \& Chen, C. (2014). The individual and collective facets of pride in Chinese college students. Basic and Applied Social Psychology, 36(2), 176-189. https://doi.org/10.1080/01973533.2014.883516

Mackie, D. M., Smith, E. R., \& Ray, D. G. (2008). Intergroup emotions and intergroup relations. Social and Personality Psychology Compass, 2(5), 1866-1880. https://doi.org/10.1111/j.1751-9004.2008.00130.x

Marques, J. M., \& Paez, D. (1994). The "black sheep effect”: Social categorization, rejection of ingroup deviates, and perception of group variability. European Review of Social Psychology, 5(1), 37-68. https://doi.org/10.1080/14792779543000011

Mashuri, A., \& Zaduqisti, E. (2014). National identification and collective emotions as predictors of pro-social attitudes toward Islamic minority groups in Indonesia. Europe's Journal of Psychology, 10(2), 255-276. https://doi.org/10.5964/ ejop.v10i2.707

McDonnell, E. M., \& Fine, G. A. (2011). Pride and shame in Ghana: Collective memory and nationalism among elite students. African Studies Review, 54(3), 121-142.

Montoya, R. M., \& Pittinsky, T. L. (2012). Individual variability in adherence to the norm of group interest predicts outgroup bias. Group Processes \& Intergroup Relations, 16(2), 173-191. https://doi.org/10.1177/1368430212450523

Nelson, J. K. (2002). Tempest in a textbook: A report on the new middle-school history textbook in Japan. Critical Asian Studies, 34(1), 129-148. https://doi.org/10.1080/146727102760166635

Newheiser, A., \& Dovidio, J. F. (2015). High outgroup entitativity can inhibit intergroup retribution. British Journal of Social Psychology, 54(2), 341-358. https://doi.org/10.1111/bjso.12078

Powell, A. A., Branscombe, N. R., \& Schmitt, M. T. (2005). Inequality as ingroup privilege or outgroup disadvantage: The impact of group focus on collective guilt and interracial attitudes. Personality and Social Psychology Bulletin, 31(4), 508-521. https://doi.org/10.1177/0146167204271713

Quin, P. (2010). Chinese national pride and East Asian regionalism among the elite university students in PRC. Journal of Asia Pacific Studies, 2(1), 28-54.

Reysen, S., \& Branscombe, N. R. (2008). Belief in collective emotions as conforming to the group. Social Influence, 3(3), 171-188. https://doi.org/10.1080/15534510802247438

Reysen, S., Katzarska-Miller, I., Nesbit, S. M., \& Pierce, L. (2013). Further validation of a single-item measure of social identification. European Journal of Social Psychology, 43(6), 463-470. https://doi.org/10.1002/ejsp.1973 
Rothschild, Z. K., Landau, M. J., Molina, L. E., Branscombe, N. R., \& Sullivan, D. (2013). Displacing blame over the ingroup's harming of a disadvantaged group can fuel moral outrage at a third-party scapegoat. Journal of Experimental Social Psychology, 49(5), 898-906. https://doi.org/10.1016/j.jesp.2013.05.005

Rydell, R. J., \& McConnell, A. R. (2005). Perceptions of entitativity and attitude change. Personality and Social Psychology Bulletin, 31(1), 99-110. https://doi.org/10.1177/0146167204271316

Salazar, A. (2016, February 9). "White guilt” video shown to high school students for Black history month. Retrieved from https://www.infowars.com/white-guilt-video-shown-to-high-school-students-for-black-history-month/

Sani, F., Bowe, M., \& Herrera, M. (2008). Perceived collective continuity and social well-being: Exploring the connections. European Journal of Social Psychology, 38(2), 365-374. https://doi.org/10.1002/ejsp.461

Schmitt, M. T., Miller, D. A., Branscombe, N. R., \& Brehm, J. W. (2008). The difficulty of making reparations affects the intensity of collective guilt. Group Processes and Intergroup Relations, 11(3), 267-279. https://doi. org/10.1177/1368430208090642

Schori-Eyal, N., Tagar, M. R., Saguy, T., \& Halperin, E. (2015). The benefits of group-based pride: Pride can motivate guilt in intergroup conflicts among high glorifiers. Journal of Experimental Social Psychology, 61(1), 79-83. https://doi. org/10.1016/j.jesp.2015.07.008

Sherif, M., \& Sherif, C. W. (1969). In-group and intergroup relations: Experimental analysis. In M. Sherif \& C. W. Sherif (Eds.), Social psychology (pp. 221-266). New York, NY: Harper \& Row.

Smeekes, A., Verkuyten, M., \& Martinovic, B. (2015). Longing for the country’s good old days: National nostalgia, autochthony beliefs, and opposition to Muslim expressive rights. British Journal of Social Psychology, 54(3), 561-580. https:// doi.org/10.1111/bjso.12097

Smith, E. R., Seger, C. R., \& Mackie, D. M. (2007). Can emotions be truly group level? Evidence regarding four conceptual criteria. Journal of Personality and Social Psychology, 93(3), 431-446. https://doi.org/10.1037/0022-3514.93.3.431

Spencer-Rodgers, J., Williams, M. J., Hamilton, D. L., Peng, K., \& Wang, L. (2007). Culture and group perception: Dispositional and stereotypic inferences about novel and national groups. Journal of Personality and Social Psychology, 93(4), 525-543. https://doi.org/10.1037/0022-3514.93.4.525

Tajfel, H. (1970). Experiments in intergroup discrimination. Scientific American, 223(5), 96-102. https://doi.org/10.1038/ scientificamerican1170-96

Tajfel, H., \& Turner, J. (1986). The social identity theory of intergroup behavior. In S. Worchel \& L. W. Austin (Eds.), Social psychology of intergroup relations (pp. 7-24). Chicago, IL: Nelson-Hall.

Tancredo, T. (2016, June 4). Seeds of disorder: High school courses now dedicated to teaching American guilt. Retrieved from https://www.breitbart.com/big-government/2016/06/04/seeds-of-disorder-civics-courses-now-dedicated-to-teaching-american-guilt/

Tollefsen, D. (2006). The rationality of collective guilt. Midwest Studies in Philosophy, 30(1), 222-239. https://doi. org/10.1111/j.1475-4975.2006.00136.X

Turner, J. C., Hogg, M. A., Oakes, P. J., Reicher, S. D., \& Wetherell, M. S. (1987). Rediscovering the social group: A self-categorization theory. Oxford, United Kingdom: Blackwell.

van Leeuwen, E., van Dijk, W., \& Kaynak, U. (2013). Of saints and sinners: How appeals to collective pride and guilt affect outgroup helping. Group Processes \& Intergroup Relations, 16(6), 781-796. https://doi.org/10.1177/1368430213485995

Wetherell, M., \& Potter, J. (1992). Mapping the language of racism: Discourse and the legitimation of exploitation. New York, NY: Columbia University Press.

Wildschut, T., Insko, C. A., \& Gaertner, L. (2002). Intragroup social influence and intergroup competition. Journal of Personality and Social Psychology, 82(6), 975-992. https://doi.org/10.1037//0022-3514.82.6.975

Wohl, M. J. A., Branscombe, N. R., \& Klar, Y. (2006). Collective guilt: Emotional reactions when one's group has done wrong or been wronged. European Review of Social Psychology, 17(1), 1-37. https://doi.org/10.1080/10463280600574815

Wohl, M. J. A., Matheson, K., Branscombe, N. R., \& Anisman, H. (2013). Victim and perpetrator groups' responses to the Canadian government's apology for the head tax on Chinese immigrants and the moderating influence of collective guilt. Political Psychology, 34(5), 713-729. https://doi.org/10.1111/pops.12017

Yzerbyt, V., Castano, E., Leyens, J., \& Paladino, M. (2000). The primacy of the ingroup: The interplay of entitativity and identification. European Review of Social Psychology, 11(1), 257-295. https://doi.org/10.1080/14792772043000059

\section{SUPPORTING INFORMATION}

Additional supporting information may be found in the online version of this article at the publisher's web site:

Vignettes 
Copyright of Political Psychology is the property of Wiley-Blackwell and its content may not be copied or emailed to multiple sites or posted to a listserv without the copyright holder's express written permission. However, users may print, download, or email articles for individual use. 